\title{
Generic Skills of Final Year University Students in Preparation towards Industrial Revolution 4.0
}

\author{
Kamarul Md Shah, Jaharudin Padli, Aqeel Khan, Rozita Jayus
}

\begin{abstract}
This study is aimed to identify the level of generic skills among final year university students in preparation towards Industrial Revolution 4.0. A total of 89 final year students from the Counseling Program had participated in this study. Data were collected using a questionnaire adapted from the generic skills questionnaire developed by SCANS, Mohamad Sattar et al., Kamaruddin , Soft Skills (KPTM) and the Malaysian Quality Framework (MQA). Among the variables studied are the skills of communication, critical thinking and problem solving, teamwork, continuous learning and information management, moral and ethics, flexibility, and self-confidence. Results of the study show that the level of generic skills of these final year students is good. The final year students also exhibited high generic skills particularly for the self-confident, teamwork, and moral and ethics constructs. However, the critical thinking and problem solving construct showed opposite results, indicating that there is a negative relationship between generic skills and achievement (CGPA). Apart from that, the results also showed that there is a significant difference between generic skills and gender, but there is no significant difference with achievement. Communication, critical thinking and problem solving, continuous learning and information management, and flexibility skills emerged as the most important factors for effective learning in the four contexts under consideration. Finally, this paper ended with suggestions of further initiatives to be taken to improve the generic skills of university students in order to meet the aspirations of the National Higher Education Development Plan and Industrial Revolution 4.0.
\end{abstract}

Index Terms: Generic skills, final year university student, achievement

\section{INTRODUCTION}

The Ministry of Higher Education Malaysia has set forth new initiatives as part of its effort to cultivate holistic, entrepreneurial and balanced graduates to be globally competitive and meet the needs of Industrial Revolution 4.0. Its minister had said that the ministry has introduced a range of initiatives such as existing academic-driven CGPA system, the 2u2i Program and CEO @ Faculty Program to address the challenges and critical needs of Industry 4.0. Academicians and students need to adapt to the changing trends and new

Revised Manuscript Received on October15, 2019

Kamarul Md Shah, Faculty of Business, Economic and Social Development, Universiti Malaysia Terengganu, 21030 Kuala Terengganu, Terengganu, Malaysia

Jaharudin Padli, Faculty of Business, Economic and Social Development, Universiti Malaysia Terengganu, 21030 Kuala Terengganu, Terengganu, Malaysia

Aqeel Khan, Faculty of Social Sciences and Humanities, Universiti Teknologi Malaysia, Skudai, Johor 81310, Malaysia

Rozita Jayus (corresponding author), Faculty of Business, Economic and Social Development, Universiti Malaysia Terengganu, 21030 Kuala Terengganu, Terengganu, Malaysia. Email: rozitaj@umt.edu.my knowledge and skills based on the cyber-physical system which is already part of everyone's lives. Although this change seems to emphasize on mastery of technology in the teaching and learning process, generic skills however remain an important part of the revolutionary Industrial 4.0.

In this era of globalization, generic skills are one of the important skills needed by university students before entering the workforce. Students need to be equipped with the skills required by the job market. It is important that these students have acquired the generic skills in order to be competitive in the job market when they graduate. Universities are expected to provide students not only with academic knowledge and skills, but also generic skills such as critical thinking, communication and collaboration, and problem-solving [1].

Acquiring teaching skills and knowledge in the field of counseling alone is not sufficient as students need to acquire generic skills as well. This coincides with the government's efforts to provide knowledge and skilled workers in line with the National Education Philosophy i.e. to produce individuals who are balanced physically, emotionally, spiritually and intellectually. The development of generic skills is often neglected in university curriculums and university teaching processes. However, it is necessary for the employability of its alumni [2]. Students' development therefore needs to be highly self-regulated, similar to lifelong learning. For lifelong learning, [3] developed a model describing the decision-making process of a potential learner. The model starts with the identification of a need. The potential learner must become aware of a discrepancy between his/her current status and the target status. To identify this discrepancy, a certain level of self-reflection is necessary. Then, the potential learner has to recognize the educational aspects of the need. This includes the idea that learning can help reduce the discrepancy. Therefore, the potential learner must have a positive attitude toward learning [4].

The classical approach of teaching and learning which is mostly based on knowledge transfer is questionable because the life cycle of knowledge is shortening while new types of jobs appear every day, accompanied by new knowledge requests. Thus, the arising question is on how to shift the focus from learning knowledge to developing generic skills [5], [6], [7] so that future professionals benefit from experiential learning. Thinking and acting should embrace new dynamics based on the whole spectrum of knowledge which comprise of rational, emotional and spiritual knowledge fields [8], [9]. 
Generic skills, also known as core skills, key skills, essential skills, basic skills, soft skills, key competences or employability skills are the capabilities that are liable to empower personal and professional development based on learning. The difficulty of implementing a new vision concerning generic skills in universities comes mostly not from professors, but from students who should work harder in developing their conceptual skills and capability of learning to learn in the changeable business environment. Learning to learn becomes the new mantra of university education so that students develop their capacity of searching for new knowledge instead of acquiring it already processed through explicit lectures. This means that students assume responsibility for their learning and developing generic skills as mechanisms that are able to handle novel issues in the changeable world.

Generic skills is general skills that can be used in a lot of work and are not specific to an occupation or industry alone i.e. from the lower level to the higher [10], [11], [12]. The level of mastery of these skills will determine a person's skills at problem solving, report writing, working in groups, learning new knowledge, and managing stress when he/she needs to operate towards successful change [11].

At present, educators need to admit, face and address the life skills or generic skills crisis for the happiness and success of students and the productiveness and success of the society [13]. The role of teachers or educators has becoming very vital and complex to ensure that the demand for generic skills is fulfilled. and argued that in the 21 st century, skills, soft skills, life skills, social skills or generic skills all carry the same meaning as defined by the [14], which is the "abilities for adaptive and positive behavior that enable individuals to deal effectively with the demands and challenges of everyday life i.e. communication/interpersonal skills, decision-making and critical thinking skills, coping and self-management skills" (pg. 1).

Students who possess academic knowledge must also be equipped with generic skills so that they have the initiative to find and master new knowledge in accordance with what is needed in the workplace. Application of soft skills amongst students should be implemented directly through the development of a specifically designed curriculum, or indirectly (embedded) through the existing curriculum at the university [15]. With the initiative mentioned above, counseling graduates can then compete in the ever-changing job market. Generic skills will ensure an individual to remain relevant and competitive in the challenging era of globalization. Generic skills are also very useful for university graduates as a set of skills needed in the world of work [16], [17]. Therefore, in addition to endeavoring to obtain a degree, students should also be involved in extra-curricular activities and experience work in counseling practice in order to build the skills needed for the workplace; in other words, to meet the market's needs in getting a job.

This study is conducted to identify the level of generic skills of counseling students from a selected university. This study will provide information for the respective bodies to be used to enhance the development of generic skills among students in universities. This paper also aims to examine the relationship between the level of students' generic skills and their academic achievement in terms of their Cumulative Grade Point Average (CGPA) of the previous semester. It is contested that if there is any significant relationship between the two variables, this study would then be able to provide and contribute new knowledge in relation to generic skills. This research will also discover the relationships (if any) between generic skills with gender and students' achievement.

\section{BACKGROUND OF STUDY}

The problem of graduates lacking generic skills has become a global issue in the 21 st century. Generic skills are so much needed locally and also in foreign countries. This is to make sure that graduates from every institute owns technical skills and can use it to face any challenges in the workplace. Most employers' highest concern is that graduates do not possess generic skills [12]. It is the responsibility of the education sector to pick-up this matter, as generic skills can be taught during the teaching and learning process. Basic education at the pre-school level is the best stage that can be manipulated to inculcate generic skills into students, even though teachers will find it difficult to make the children understand. Although children spend more time away from home on a daily basis, parents should also be given the responsibility to ensure that their children are equipped with these skills.

A majority of employers all over the world have found that most applicants lack generic skills Reference [11], [18] shows, it is hard to get employees who have mastered many generic skills. The latest trend in employment is that most employers choose to focus on the generic skills a graduate have mastered and the knowledge they have gained, rather than on his/her degree certificate. They also emphasize on other skills such as communication skills, team working and problem solving skills [19], [20], [21]. Therefore, most employers put hope on educational institutes to focus on the development of generic skills amongst their students. Undergraduates should be trained systematically with the knowledge and skills needed in the industry in order to increase their employability. However, the "Diploma Disease" has declined the call for generic skills' urgency [22]. The "Diploma Disease" focuses on learning for certification purposes. If no serious action is taken by the education authorities, this problem will hinder the process of humanizing the people in education.

Moreover, reference [23] shows employers often suggest the importance of students who come out from the school system to be equipped with skills to make decisions and think critically and creatively. Based on his experience, many students who are employed have less initiative and are not imbued with a culture of knowledge that can push their lifelong learning. Instead, these new hires rely on others to make decisions for them.

The increased rate of unemployment among graduates has also been reported [24]. The report highlighted that aspects such as mature thinking, personality development, 
leadership, intellectual culture, and soft skills which should fall within the context of integrated education are sometimes not prominent, especially in university students.

This shows that university students' lack generic skills. Graduates also possess low levels of other types of skills such as personality or ethics, problem solving and critical thinking. In addition, graduates are also said to have less mastery of language or communication skills. Therefore, this study is conducted to see the truth of the phenomenon, especially among students from high education institutions. Reference [25] emphasized that the central point to teaching is the teachers' ability to transfer and transform students. It is therefore important for educators to provide and offer the best teaching practices to their students in order to ensure that the transfer and transform process occur (pg. 2). Reference [26] highlighted that skilled and trained educators are required to teach generic skills to students. Both of these factors really emphasize the importance of teachers' and educators' role in developing generic skills. Teaching quality indirectly reflects students' learning quality. However, there is no indication that confirms the best time in the academic calendar to teach generic skills. Thus, the question whether the skills should be incorporated in the curriculum or not is still contented (pg.3). A research conducted by reference [5] discovered that generic skills can be incorporated in teaching via corporative learning. They also discovered that students with different abilities were able to improve their generic skills through corporative learning. As technology develops at a very rapid speed, the research had also discovered the possibility of teaching generic competencies through virtual learning [27]. This finding has provided an alternative mechanism to teaching generic skills together with the possibility of the non-face-to-face teaching and learning of generic skills. The world of teaching and learning is evolving. The most important point is to sustain the real purpose of education, regardless of the medium and methodology adopted. The sustainment of the real purpose in education also refers to sustaining and enhancing these skills in students. It is evident that the role of educators is central to the success of it.

\section{RESEARCH OBJECTIVES}

The purpose of this study is to identify the level of generic skills of final year students. In addition, this study also aims to identify the levels of generic skill based on constructs i.e. communication, critical thinking and problem solving, teamwork, continuous learning and information management, ethics and moral, flexibility, and self-confidence. The study also aims to identify the relationship between generic skills and students' achievement (CGPA). Furthermore, the study also wants to identify whether there is a difference in generic skills according to gender and achievement (CGPA).

\section{METHODOLOGY}

This study had employed a survey research design as its methodology. The survey design was chosen as reference [28] had mentioned that it is suitable to be used to identify trends in attitudes, opinions, behavior or characteristics. This research used a cross-sectional survey as it tried to measure the generic skills of 89 final year students from a selected university. The instrument used in this research was adapted from the generic skills questionnaire developed by reference [29], [30], [31], [32], [33]. This instrument has been used by reference [34] and has an Alpha Cronbach value of 0.89. The instrument consists of Part A and Part B. Part A consists of five items on demographic details, and Part B consists of 34 items on generic skills which include the constructs of communication, critical thinking and problem solving, teamwork, continuous learning and information management, moral and ethics, flexibility, and self-confidence. A five-point Likert scale ranging from (5) representing "strongly agree" to (1) representing "strongly disagree" was used as the answer scale for a series of statements designed to determine students' perceived levels of generic skills. Prior to distribution, the students involved were informed of the purpose of the study and were assured that the result of the study will be used for research purposes only. The researchers administered the instrument themselves.

\section{RESULTS OF THE STUDY}

This part discusses the results of the study based on the research questions. The discussion is based on the literature.

\section{A. Level Of Generic Skills Of The Final Year} Students

The results showed that the mean for generic skills of the respondents is 3.99 , which is considered high $(3.01-4.00)$. This may be because the learning modules or curriculum at the university have fulfilled the need to teach generic skills such as communication skills, group working skills, problem-solving skills, adapting/flexibility skills, long-life learning and information management, ethics and morale, and also self-confidence. Evidently, all of these constructs are applied during the teaching and learning process either in or out of the classroom and also during the on-going assessments practiced at the university.

Table 1: The Level of Generic Skills of Final Year Students

\begin{tabular}{lccc} 
Variables & $\mathbf{N}$ & Min & $\begin{array}{c}\text { Standard } \\
\text { Deviation }\end{array}$ \\
\hline $\begin{array}{l}\text { Generic } \\
\text { Skills }\end{array}$ & 89 & 3.99 & 0.447 \\
\hline
\end{tabular}

\section{B. Level of Generic Skills based on Construct}

Table 2 depicts the level of generic skills based on construct. There are eight constructs measured namely communication skills, critical thinking skills, teamwork skills, flexibility skills, lifelong learning and information management skills, ethics and moral skills, and self-confidence enhancement skills. Three constructs showed high mean scores $(4.01-5.00)$. 
The group work skills scored the highest mean (4.10) followed by self-confidence skills (4.07) and ethics and moral skills (4.05). However, communication skills scored the lowest mean (3.93). The result shows that these final year students possess some generic skills, but still need to equip themselves with other generic skills.

Table 2: Level of Generic Skills Based on Construct

\begin{tabular}{lccc}
\hline \multicolumn{1}{c}{ Construct } & $\mathbf{N}$ & Mean & S.D \\
\hline Communication & 89 & 3.93 & 0.518 \\
$\begin{array}{l}\text { Critical Thinking and } \\
\text { Problem Solving }\end{array}$ & 89 & 4.10 & 0.513 \\
Team Work & 89 & 3.80 & 0.554 \\
$\begin{array}{l}\text { Flexibility } \\
\text { Lifelong Learning } \\
\text { and Information } \\
\text { Management }\end{array}$ & 89 & 3.95 & 0.523 \\
$\begin{array}{l}\text { Ethics and Moral } \\
\text { Self-confident }\end{array}$ & 89 & 3.97 & 0.536 \\
\hline
\end{tabular}

\section{Correlation between Generic Skills and Achievement}

Using the Spearman Rho correlation analysis, the result indicated that the final year students' generic skills are correlated with achievement. According to Table 3, r [89] = $0.909, p=-0.013(p>0.01)$. The result shows that there is a negative correlation between generic skills and achievement. Therefore, it is believed that the higher the generic skills of the final year students, the lower their learning achievement and performance. This means that generic skills are not related to the final year students' achievement at the earlier stages of study at the university.

Table 3: Correlation between Generic Skills and Achievement

\begin{tabular}{lc}
\hline \multicolumn{1}{c}{ Variable } & Achievement \\
\hline Generic skills & -0.013 \\
Significant & 0.909 \\
$\mathrm{~N}$ & 79 \\
\hline
\end{tabular}

\section{Generic Skills Based on Gender and Achievement}

A t-test analysis showed that there is a significant difference between gender among the respondents, $t(103)=$ $34.451, p=0.000(p>0.05)$. This indicates that different genders have different generic skill levels. (Table 4)

Table 4: T-test Analysis Based on Gender

\begin{tabular}{cccc}
\hline Variable & t-statistic & df & Sig. \\
\hline Gender & 43.719 & 88 & 0.000 \\
\hline \multicolumn{2}{c}{$\mathrm{p}>0.05$} \\
The result also showed that there is no significant
\end{tabular}

difference between the final year students' achievement and generic skills as $\mathrm{F}(14.476)=0.912$ and $\mathrm{p}=0.440(\mathrm{p}>0.05)$. (Table 5)

Table 5: Anova Analysis Based on Achievement

\begin{tabular}{ccccc} 
Variable & $\begin{array}{c}\text { F } \\
\text { value }\end{array}$ & $\begin{array}{c}\text { DK } \\
\text { Between }\end{array}$ & $\begin{array}{c}\text { DK in } \\
\text { Group }\end{array}$ & $\begin{array}{c}\text { level of } \\
\text { Sig } \\
\text { in-group }\end{array}$ \\
\hline Achievement & 14.46 & 3 & 84 & 0.440
\end{tabular}

\section{FINDINGS AND DISCUSSIONS}

The findings of the study indicated that the final year students' level of generic skills is good as its mean score was 3.99 on the Five Point Likert Scale. The finding reflects the teaching and learning process at the university, together with the students' previous training at other educational institutions before continuing their studies at the university. This also includes co-curriculum activities which are compulsory for all students. These activities were meant to equip students to be a well-rounded person as claimed by the National Higher Education Development Plan and Industrial Revolution 4.0. This also explains the university's role in ensuring that generic skills are instilled amongst students. All undergraduate programs offered by public higher learning institutions in Malaysia are now required to incorporate generic skills in their curricular. This generic skill requirement is subject to reviews when programs are accredited and rated for quality assurance by the Ministry of Higher Education. In order to satisfy this requirement, Universiti Malaysia Terengganu (UMT) as a new university has been proactive in redesigning its existing curriculum to be more competitive and marketable by integrating and implementing generic skills in the curriculum [35].

This study also discovered that there is a negative relationship between generic skills and academic achievement. High academic achievement does not guarantee high generic skills. The finding is dissimilar to other researches' findings such as those by reference [34], [26] which had indicated that academic achievement (GPA) is positively related to generic skills such as critical thinking, problem solving and communication. This situation may be because the researches were conducted on new students who were adapting to the university's learning system and thus were trying to equip themselves with a variety of skills, especially generic skills for the future. Teaching and learning accompanied by understanding will enable students to realize what is obtained and gathered in the classroom that can be used in real life. Teachers who teach with understanding will realize that students appreciate his/her teaching by showing good attitudes. This means that good generic skills can also help improve academic achievement. A research by reference [36] suggested the need for accounting educators to see skills development as an essential element of the path to providing a successful accounting experience. Other studies have shown that the characteristics of good mathematics lecturers do inspire. They can inspire other mathematics lecturers and educators in general. Based on students and lecturers' perspective, some characteristics of good mathematics lecturers are such as mastering the materials well, being on 
time, being objective, understanding students, presenting the materials clearly, and being disciplined. Some other characteristics mentioned are like teaching eagerly, being unhurried, being friendly, giving good examples, and preparing lessons well. These characteristics are not much different from the characteristics described by some previous researchers and some theories, i.e. mastering the subject matter well, being pedagogic, and working wholeheartedly [37].

These findings reveal that generic skills need to be understood, learnt and taught properly and meaningfully. The skills require good cognitive ability and critical thinking. For example, some generic skills such as critical thinking and problem solving require higher order thinking. This also reflects the importance for counselors to be exposed to higher order thinking skill in order to be critical and able to solve problems. The counseling industry is a very challenging place, thus counselors need to be prepared to face any uncertainties. Recommendations on the development of generic skills have been widely accepted by public consultation. It is evident that generic skills cannot be developed in a vacuum, but should instead be developed through the learning and teaching process of the Key Learning Area (KLA) by subject, General Studies for Primary Schools, or in other contexts and activities such as project learning, reading, and interactive learning on the Internet. Generic skills are fundamental in helping students to learn on how to acquire knowledge, construct knowledge and apply knowledge to solve new problems [38]. One way to do this is to ensure that these generic skills are nurtured since the beginning of the students' academic year. The study also discovered that there is no significant difference between generic skills and achievement. Finally, the research discovered that there is a significant different of generic skills scores between male and female final year students. Female students showed higher generic skills scores compared to male students.

\section{CONCLUSION}

In conclusion, the effort to conduct this research is beneficial mainly to universities as well as high-education related bodies. The life skills "crisis" happens when there is a mismatch between what is acquired in the lecture room and what is demanded in real life, especially in the workplace. It is vital for high educational institute providers to seriously consider the inculcation of generic skills in its curriculum. The findings of this research provide precious information for the respective authorities to reconsider the content of their syllabus as well as give more attention to producing mechanisms that can ensure the nurturing of generic skills during students' training period. Hopefully the skills will last and are manifested when the counselors (study respondents) are posted to their workplaces. This proposal will only be successful with collaboration between educators and providers. The study provides new information on the generic skills profiles of final year students. It will be worth to study in the future the extent to which various generic skills are reflected in the teaching and learning processes. Knowledge on students' generic skills can be added to by investigating whether students' generic skills profiles differ across disciplines. Malaysia is in the era of Industrial Revolution 4.0 which brings upon rapid technological developments, especially in the form of the internet which makes the world a borderless place. Thus, good generic skills will make Malaysia more balanced from the humanity aspect. Therefore, good generic skills will support and move in parallel with Industrial Revolution 4.0 which is a priority of the Malaysian Ministry of High Education.

\section{REFERENCES}

1. D. Kember, M. Charlesworth, H. Davies, J. McKey, \& V. Stott, "Evaluating the effectiveness of educational innovations: using study process questionnaire to show that meaningful learning occurs." Studies in Educational Evaluation, 23(2), (1997). pp 141-157.

2. N. Schaper, T. Schlömer, \& M. Paechter, "Editorial: Kompetenzen, Kompetenzorientierung und Employability in der Hochschule. Zeitschrift für Hochschulentwicklung," 7(4), (2012). pp 1-4.

3. H. Baert, K. D. Rick, \& K. V. Valckenborgh, "Towards the conceptualization of learning climate. In R. Vieira de Castro, A. V. Sancho, \& P. Guimaraes (Eds.)," Adult education: New routes in a new landscape Braga, Portugal: University of Minho. (2006). pp. 87-111.

4. E. Kyndt, \& H. Baert, "Antecedents of employees' involvement in work-related learning: A systematic review." Review of Educational Research, 82(3), (2013). pp 273-313.

5. J. Ballentine, and P.McC. Larres, "Coorporative Learning: a pedagogy to improve students" Generic Skills, Education and Training Vol 49 (2). (2007). DOI: 10.1108/00400910710739487

6. A. Goatman, and D. Medway, "A future for undergraduate education in UK business schools?", Journal of Marketing for Higher Education, Vol. 21 No. 1, (2011), pp. 107-114

7. H. Singh, and M. Gera, "Generic skills for sustainable development", Indian Journal of Research, Vol. 4 No. 6, (2015), pp. 290-291.

8. E. Bolisani, and A. Oltramari, "Knowledge as a measurable object in business contexts: a stockand-flow approach", Knowledge Management Research \& Practice, Vol. 10 No. 3, (2012), pp. 235-286.

9. C. Bratianu, "Organizational Knowledge Dynamics: Managing Knowledge Creation, Acquisition, Sharing, and Transformation, IGI Global, Hershey," PA. (2015),

10. S.M. Abdelhalim, "Children Literature Based Program for Developing EFL Primary Pupils' Life Skills and Language Learning Strategies.” English Language Teaching Vol 8(2) (2015). DOI:10.5539/elt.v8n2p178.

11. M. Z. Kamsah "Developing Generic Skills in Classroom Environment: Engineering Students' Perspective.”: Conference On Engineering Education (CEE 2004), 14-15 December 2004, Kuala Lumpur. (2004).

12. K. Cotton, "Developing Employability Skills." School Improvement Research Series: Northwest Regional Educational Laboratory. (2001).

13. A. Esa, J. M. Yunus, and N. Kaprawi "Peranan Kokurikulum dalam Pembangunan Kemahiran Generik" Jurnal Sains Sosial. KUiTTHO: Jilid 2. Bil 1. (2004). pp 1-7.

14. World Health Organization. "WHOQOL Study Protocol." WHO/MNH/PSF/93.9, Geneva. (1993).

15. R. Will, W. Sue, and M.E. Deborah, "Mapping Generic Skills Curricula: A Recommanded Methodology". Journal of Further and Higher Education Vol. 29, No. 3, August, (2005). pp 221-231.

16. M. Kwok, "Disciplinary Differences in the Development of Employability Skills of Recent University Graduates in Manitoba: Some Initial Findings." Higher Education Perspectives, 5(1), (2004). Pp 60-77.

17. J. Gibb, and P. Curtin, "Overview: Generic Skills: Research Readings." Kengsington Park: National Centre for Vocational Education Research (NCVER) Ltd. (2004).

18. J. P. Robinson, "The Workplace." Alabama Cooperative Extension System. v1 (3). (2000).

19. Australian Chamber of Commerce and Industry (ACCI) "Employability Skills-an Employers' Perspective." (2002). http://www.actchamber.com.au/PDF/EmployabilitySkillsOverview.pdf Retrieved on 14 March 2006.

20. GCA, "Graduate Destinations 2005." Melbourne: Graduate Careers Australia. (2006).

21. Z. Hassan, M. A. A. Rahman, M. N. A. Ghaffar and K. Zakaria "Penerapan kemahiran generik dalam pengajaran kejuruteraan di Sekolah Menengah Teknik di Terengganu." Johor : Universiti Teknologi Malaysia (2005) 
22. D. Ronald, "The Diploma Disease Revisited.” Institute of Development Studies (IDS) Bulletin 11.2. (1980).

23. J.A Philips, "Pengajaran Kemahiran Berfikir." Kuala Lumpur: Utusan Publications \& Distributors Sdn. Bhd. (1997).

24. Berita Harian Kaedah 'Ranking' Tempatan IPT Kembalikan Peranan Sebenar. Bernama. Berita Harian, 7 Ogos 2007.

25. L.S. Shulman, "The Scholarship of Teaching and Learning: A Personal Account and Reflection." International Journal for the Scholarship of Teaching and Learning Vol 5(1) (2011). http://www.georgiasouthern.edu/ijsotl

26. B.T. B. Paul, E. P. Philippa, and K.L. Harris, "Developing Generis Skills Through University Study: a study of arts, science and engineering in Australia. Higher Education” Vol. 60. (2010). DOI: $10.1007 / \mathrm{s} / 10734-010-9308-8$

27. I. Gvaramadze, "Developing generic competencies in online virtual education programmes at the University of Deusto." Campus- Wide Information System 20(1) Vol. (2012) DOI:10.1108/10650741211192028

28. J. W. Creswell, "Educational research: Planning, conducting, and evaluating quantitative and qualitative research." New Jersey: Pearson Prentice Hall. (2005).

29. Secretary's Commission on Achieving Necessary Skill. Skills and Task for Jobs.A SCANS Report for America 2000. Washington, D.C. (2001).

30. M. S. Rasul, M. Yusof , N. M. Rashid and R. Amnah. "Pembangunan Standard Pengukuran Kemahiran." (2008).

31. K. M. Tahir. "Penilaian Pembangunan kemahiran Generik Dalam Kalangan Pelajar Tahun Akhir Kolej Komuniti Kementerian Pengajian Tinggi." Unpublished PhD Thesis. Universiti Kebangsaan Malaysia. (2010).

32. Kementerian Pengajian Tinggi "Modul Pembangunan Kemahiran Insaniah (Softskills) untuk Institusi Pengajian Tinggi Malaysia." Universiti Putra Malaysia. Serdang. (2006).

33. Malaysian Quality Agency. "Malaysian Qualification Framework: MQA Guide book. 'Employability'.” Jurnal Teknologi, 49(E) Dis. 2008: (2005). pp 15-30.

34. K. M. Shah., F. Mukhtar., H. Abdullah., M. A. Malek., \& Z. M. Syukur "Kemahiran generic dan pencapaian akademik dalam kalangan guru pelatih di Institut Pendidikan Guru Malaysia." Jurnal Pendidikan Malaysia, 42 (1), (2017). pp 61-67.

35. S. Yassin, F.A. Hasan, W. Amin, \& N. Amiruddin. "Implementation of generic skills in the curriculum", Proceedings of the EDU-COM 2008 International Conference. Sustainability in Higher Education: Directions for Change,Edith Cowan University, Perth Western Australia, $\quad 19-21 \quad$ November $2008 . \quad$ (2008) http://ro.ecu.edu.au/ceducom/54

36. G. Stoner, \& M. Milner, "Embedding generic employability skills in an accounting degree: development and impediments." Accounting Education: an international journal, 19(1-2), (2010) pp.123-138.

37. T. Hapsari, D.P. Putri, \& J.F. Raharjo, "Characteristics of good mathematics lecturers based on students and lecturers perspectives." In AIP Conference Proceedings Vol. 1848, No. 1, p. 040004. AIP Publishing. (2017)

38. Hong Kong Special Administrative Region of the People's Republic of China, Learning To Learn. (2000) Curriculum Development Council.

\section{AUTHORS PROFILE}

First Author Dr. Kamarul Md Shah is currently a University Lecturer at Department of Counselling and Psychology, Faculty of Business, Economic and Social Development, Universiti Malaysia Terengganu. He holds a Ph.D. in Counselling from National University of Malaysia. He is also a registered counselor with the Malaysian Counselor Board. He has published several books in the field of multicultural counseling and Islamic counseling. He has also published journal articles on multicultural counseling competencies, resilience among trainee teachers, wellness and generic skills among university students.

Second Author Dr. Jaharudin Padli is currently a University Lecturer at the Department of Economics, Faculty of Business, Economic and Social Development, Universiti Malaysia Terengganu. He holds a $\mathrm{PhD}$ in Economics from Universiti Putra Malaysia. He has published several books and journal articles in his area of research. His current research topics include: Economics of Crime; Economics of Climate Change; Natural Disasters and Environmental Quality; Economics of War and Terrorism, Development Economic and Islamic Economics.

Third Author : Dr. Aqeel Khan, Faculty of Social Sciences and Humanities, Universiti Teknologi Malaysia (UTM), Skudai, Johor,
Malaysia. Dr. Khan published 70 papers in scopus and his $\mathrm{H}$ index is 10 . Dr. Khan giving many keynotes and training for publication.

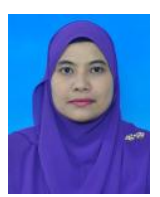

Fourth Author (corresponding author)

Pn Rozita Jayus is currently a University Lecturer at Department of Counselling and Psychology, Faculty of Business, Economic and Social Development, Universiti Malaysia Terengganu. She holds a Master in Education (Guidance and Counselling) from University Technology Malaysia. She is also a registered counselor with the Malaysian Counselor Board. She has published several articles and journal in Person with disabilities, counselling ethics towards Client with disabilities and multicultural counselling.
Published By:

Blue Eyes Intelligence Engineering

$905 \&$ Sciences Publication 